\title{
OPEN Author Correction: The intersection between spliff usage, tobacco smoking, and having the first joint after waking
}

\author{
Navin Kumar, Cheneal Puljević, Jason Ferris, Adam Winstock \& Monica J. Barratt \\ Correction to: Scientific Reports https://doi.org/10.1038/s41598-020-64110-4, published online 06 May 2020
}

The original version of this Article contained typographical errors in the Abstract.

"Compared to those who smoked tobacco and used spliffs, the following spliff use behaviour groups were less likely to have their first joint within 60 minutes after waking: those who smoked tobacco and used spliffs (95\%CI: 0.605-0.988); those who never smoked tobacco and did not use spliffs (95\%CI: 0.489-0.892); those who never smoked tobacco and used spliffs (95\%CI:0.022-0.915)."

now reads:

"Compared to those who smoked tobacco and did not use spliffs, the following spliff use behaviour groups were less likely to have their first joint within 60 minutes after waking: those who smoked tobacco and used spliffs (95\%CI: 0.605-0.988); those who never smoked tobacco and did not use spliffs (95\%CI: 0.489-0.892); those who never smoked tobacco and used spliffs (95\%CI:0.022-0.915)."

This has now been corrected in the PDF and HTML versions of the Article.

(i) Open Access This article is licensed under a Creative Commons Attribution 4.0 International License, which permits use, sharing, adaptation, distribution and reproduction in any medium or format, as long as you give appropriate credit to the original author(s) and the source, provide a link to the Creative Commons license, and indicate if changes were made. The images or other third party material in this article are included in the article's Creative Commons license, unless indicated otherwise in a credit line to the material. If material is not included in the article's Creative Commons license and your intended use is not permitted by statutory regulation or exceeds the permitted use, you will need to obtain permission directly from the copyright holder. To view a copy of this license, visit http://creativecommons.org/licenses/by/4.0/.

(c) The Author(s) 2020 